\title{
IMMUNOGLOBULIN E-RHEUMATOID FACTOR IN JUVENILE RHEUMATOID ARTHRITIS
}

\author{
Rosa Aparecida Ferreira ${ }^{1}$, Virgínia Paes Leme Ferriani ${ }^{2}$, Mônica Camargo Sopelete ${ }^{1}$, \\ Deise Aparecida Oliveira Silva ${ }^{1}$, José Roberto Mineo ${ }^{1}$, Maria Helena Bittencourt \\ Kiss $^{3}$ and Carlos Henrique Martins Silva ${ }^{1}$
}

RHCFAP/3095

FERREIRA RA et al. - Immunoglonulin E-rheumatoid factor in juvenile rheumatoid arthritis. Rev. Hosp. Clín. Fac. Med. S. Paulo 57(5): 209-216, 2002.

OBJECTIVES: To determine the presence of immunoglobulin E-rheumatoid factor in patients with juvenile rheumatoid arthritis and to correlate it with clinical and laboratory parameters.

METHODS: A multicenter prospective study was carried out from January 1993 to January 1999 with the enrollment of 3 centers of pediatric rheumatology. Ninety-one children with juvenile rheumatoid arthritis diagnosed according to the American College of Rheumatology criteria were studied: 38 (42\%) with systemic, 28 (31\%) with pauciarticular, and 25 (27\%) with polyarticular onset. Ages ranged from 2.1 years to 22.6 years (mean $10.5 \pm 4.7$ ), with 59 (65\%) girls. The control group consisted of 45 healthy children. The detection of immunoglobulin E-rheumatoid factor was carried out utilizing an enzyme-linked immunosorbent assay. Associations of immunoglobulin E-rheumatoid factor with immunoglobulin Mrheumatoid factor (latex agglutination test), total serum immunoglobulin E, erythrocyte sedimentation rate, antinuclear antibody, and functional and radiological classes III or IV were analyzed.

RESULTS: Positive immunoglobulin E-rheumatoid factor was found in $15(16.5 \%)$ of the 91 children with juvenile rheumatoid arthritis: 7 (18.5\%) with systemic, 5 (18\%) with pauciarticular, and $3(12 \%)$ with polyarticular onset. A significant correlation was observed between immunoglobulin E-rheumatoid factor and total serum immunoglobulin E in the juvenile rheumatoid arthritis patients. No correlation was found between immunoglobulin E-rheumatoid factor and positive latex agglutination slide test, erythrocyte sedimentation rate, antinuclear antibody, or the functional and radiological classes III or IV in any disease onset group. In 4 out of 45 control children (8.9\%), immunoglobulin E-rheumatoid factor was positive but with no correlation with total serum immunoglobulin E levels.

CONCLUSIONS: Immunoglobulin E-rheumatoid factor could be detected in $16.5 \%$ of juvenile rheumatoid arthritis patients, particularly in those with high levels of total serum immunoglobulin E, and immunoglobulin E-rheumatoid factor appears not to be associated with disease activity or severity.

DESCRIPTORS: Rheumatoid factor. Immunoglobulin E. Juvenile rheumatoid arthritis. ELISA.

\section{INTRODUCTION}

Rheumatoid factors (RF) are specific autoantibodies directed against antigenic determinants on the $\mathrm{Fc}$ fragment of the IgG molecule ${ }^{1}$. However, RFs are not unique to rheumatoid arthritis; they sometimes occur in normal elderly individuals, healthy immunized individuals, and patients with other autoimmune diseases or chronic infections ${ }^{2}$. Several studies have shown that only $5 \%$ to $25 \%$ of children with juvenile rheumatoid arthritis (JRA) have positive latex agglutination tests for $\mathrm{RF}^{3}$.

From the School of Medicine, Federal University of Uberlândia ${ }^{1}$, School of Medicine of Ribeirão Preto, University of São Paulo ${ }^{2}$ and from the Pediatric Department, Children's Institute, School of Medicine, University of São Paulo ${ }^{3}$.
RFs of the IgM immunoglobulin class can be detected by employing the commonly used agglutination test. These antibodies directed to IgG are the "classic" RFs that are associated with adult-onset rheumatoid arthritis. They are found in only a small subgroup of children who have RF-positive polyarthritis, the disease that is probably the childhood equivalent of classic adult rheumatoid arthritis ${ }^{4}$. 
Children with JRA who are RF positive are likely to be girls, to be older at disease onset, and to have many joints involved. It has been suggested that they have more roentgenographic evidence of bony erosion and an overall poorer prognosis than their rheumatoid factor-negative counterparts ${ }^{5}$. Some clinical and immunogenetic associations are well known, such as nodes, bony erosions, functional incapacities, and HLA Dw4 (DRB1*0401) and Dw14 (BRB1*0404) associations ${ }^{5,6}$.

In one-third of patients with JRA who present idiotypic expression with cross-reaction for RF, classical RF (IgM-RF) is not observed ${ }^{7}$. It is possible that in this group of patients, other RF isotypes are present ${ }^{8}$. With the use of ELISA, an increased detection is observed in JRA, with IgM-RF being demonstrated in $22 \%$ to $35 \%$ of patients, IgG-RF in $4 \%$ to $6 \%$, and IgA$\mathrm{RF}$ in $30 \%$ to $60 \%$, depending on the type of disease onset ${ }^{9-11}$. The presence of IgA-RF and IgM-RF has been observed in a varying percentage of children with JRA, mainly in the polyarticular onset type ${ }^{12,13}$. However, the frequency and clinical and prognostic roles of the other RF isotypes (IgG and $\mathrm{IgE}$ ) in JRA are still unknown ${ }^{14}$.

There is evidence suggesting that IgE-RF is associated with extra-articular rheumatoid vasculitis and activity of the disease in rheumatoid arthritis $^{15,16}$. We found 1 study about IgE-RF in JRA in the literature ${ }^{17}$. These investigators observed that sera from 11/26 children with JRA had low concentrations of IgE-RF detected by the indirect immunofluorescence technique and suggested that IgE-RF may be involved in the pathogenesis of JRA and rheumatoid arthritis by eliciting type I and III reactions ${ }^{17}$.

The aims of the present study were to determine the presence and the levels of IgE rheumatoid factor (IgE-RF) in children with JRA and to correlate its presence with sex, age at onset, dis- ease duration, activity of disease, erythrocyte sedimentation rate, antinuclear antibody, total serum IgE, IgMRF (latex agglutination), and functional and radiological classes III or IV.

\section{PATIENTS AND METHODS}

\section{Patients}

A prospective, multicentric study was carried out from January 1993 to January 1999. Ninety-one children (59 girls) with JRA diagnosed according to the American College of Rheumatology criteria ${ }^{18,6}$ were studied. Sera were randomly obtained from patients who visited one of the following three Centers of Pediatric Rheumatology: Hospital de Clínicas da Universidade de São Paulo, São Paulo (51 cases), Hospital de Clínicas da Faculdade de Medicina de Ribeirão Preto da Universidade de São Paulo, Ribeirão Preto, São Paulo (28 cases), and Hospital de Clínicas da Universidade Federal de Uberlândia, Minas Gerais (12 cases). The age of the patients ranged from 2.1 to 22.7 years (mean $10.5 \pm$ 4.7). The type of disease onset was systemic in 38 children, pauciarticular in 28 , and polyarticular in 25 .

Forty-five healthy control children with no symptoms of connective tissue disease or acute or chronic infections were selected from the pediatric outpatient clinic. The mean age of controls was $5.5 \pm 3.3$ years.

\section{Inclusion criteria}

All patients included had no clinical symptoms suggestive of allergic rhynitis, asthma, or atopic dermatitis. In addition, they had 3 samples of feces examined for helminths with negative results. None of the JRA patients were receiving or had received gold salts or D-penicilamine.

\section{METHODS}

Serum was obtained from each patient during the first appointment after obtaining fully informed consent from their parents or relatives. Approval for the study was also obtained from the 3 Institutional Ethics Committees. Serum samples were stored at $-20^{\circ} \mathrm{C}$.

The demographic and clinical characteristics of the JRA patients are shown in table 1 (sex, age at onset, disease duration, and activity of disease). Serum was obtained from each patient for the following laboratory measurements: erythrocyte sedimentation rate (by the Wyntrobe method), antinuclear antibody (by the Hep 2 immunoassay method), and total serum IgE (measured by monoclonal antibody-based ELISA modified from a previously described radioimmunoassay (RIA) by Pollart ${ }^{19}$ ). Values of total $\mathrm{IgE} \geq 300 \mathrm{IU} / \mathrm{mL}$ were considered abnormally high (positive $)^{20}$. IgM-RF was determined by the latex agglutination slide test using a commercially available kit (RapiTex ${ }^{\circledR}$ RF, Hoechst, Marburg, Germany). Samples with RF of $20 \mathrm{IU} / \mathrm{mL}$ or more were considered to be positive.

Active disease was defined by the presence of joint swelling or limitation of mobility with warmth, pain, or tenderness in 1 or more joints. Severity was evaluated according to Steinbrocker's functional and radiological classes ${ }^{21}$ with classes III and IV denoting major dysfunction.

\section{Quantitative determination of the IGE rheumatoid factor by ELISA}

IgE-RF was determined by a standard ELISA technique according to SILVA $^{22}$, with some modifications. The samples were always analyzed in duplicate.

Briefly, polystyrene microtiter plates were coated with $10 \mu \mathrm{g} / \mathrm{mL}$ of mouse $\mathrm{IgG}$ in $0.06 \mathrm{M}$ carbonate buffer, $\mathrm{pH} 9.6$, overnight at $4^{\circ} \mathrm{C}$. Plates were 
Table 1 - Clinical and laboratory features of the children with juvenile rheumatoid arthritis $(n=91)$ according to disease onset (systemic, pauciarticular, or polyarticular).

\begin{tabular}{|c|c|c|c|c|}
\hline \multirow[t]{2}{*}{ Clinical and Laboratory Features } & \multicolumn{4}{|c|}{ JUVENILE RHEUMATOID ARTHRITIS } \\
\hline & $\begin{array}{l}\text { Total } \\
(\mathrm{n}=91)\end{array}$ & $\begin{array}{l}\text { Systemic } \\
(\mathrm{n}=38)\end{array}$ & $\begin{array}{l}\text { Pauciarticular } \\
(\mathrm{n}=28)\end{array}$ & $\begin{array}{l}\text { Polyartycular } \\
(\mathrm{n}=25)\end{array}$ \\
\hline Females & $59(64.4 \%)$ & $21(55,3 \%)$ & $17(60.71 \%)$ & $21(84 \%)$ \\
\hline Age (years) & $10.5(2.1-22.7)$ & $11(4.1-20.8)$ & $9.9(2.4-17.2)$ & $10.3(4.2-18.6)$ \\
\hline Disease duration (years) & $5.2(0.2-17.3)$ & $6.2(1.1-13.6)$ & $4.4(0.7-10.2)$ & $3.7(0.2-11.6)$ \\
\hline Age at onset (years) & $5.2(0.5-16.1)$ & $4.7(1.4-11.9)$ & $5.5(1.1-13.3)$ & $6.7(2.9-12.2)$ \\
\hline Active disease & $50(55 \%)$ & $21(55.3 \%)$ & $12(42.8 \%)$ & $17(68 \%)$ \\
\hline Erythrocyte sedimentation rate $(>20 \mathrm{~mm} / \mathrm{h})$ & $54(59 \%)$ & $26(68.4 \%)$ & $12(42.8 \%)$ & $16(64 \%)$ \\
\hline Anti nuclear antibody + & $19(21 \%)$ & $1(2.6 \%)$ & $8(28.6 \%)$ & $10(40 \%)$ \\
\hline Rheumatoid factor (latex agglutination + ) & $5(5.4 \%)$ & - - & -—— & $5(20 \%)$ \\
\hline Functional class (III/IV) & $13(14 \%)$ & $11(28.9 \%)$ & - - - & $2(8 \%)$ \\
\hline Radiological class (III/IV) & $49(54 \%)$ & $26(68.4 \%)$ & $10(35.7 \%)$ & $13(52 \%)$ \\
\hline Elevated total serum IgE $(>300 \mathrm{IU} / \mathrm{mL})$ & $54(59.3 \%)$ & $26(68.4 \%)$ & $15(53.6 \%)$ & $13(52 \%)$ \\
\hline
\end{tabular}

washed in $0.01 \mathrm{M}$ phosphate buffered saline (PBS), pH 7.2, containing $0.05 \%$ Tween 20 (PBS-T) and blocked with PBS-T plus $1 \%$ bovine serum albumin (PBS-T-BSA) for $1 \mathrm{~h}$ at room temperature (RT). Washings in PBS-T were done between the steps of the reaction. The plates were incubated with serum samples diluted 1:5 in PBS-T, in duplicate, for $1 \mathrm{~h}$ at RT. Subsequently, peroxidase-rabbit IgG anti-human IgE, prepared as described by Wilson and Nakane $^{23}$, at 1:500 in PBS-T was added and incubated for $1 \mathrm{~h}$ at RT. Finally, enzymatic substrate consisting of $0.03 \% \mathrm{H}_{2} \mathrm{O}_{2}$ and ortho-phenylenediamine in $0.1 \mathrm{M}$ phosphate citrate buffer, pH 5.0, was added and incubated for $15 \mathrm{~min}$ at RT. Adding $2 \mathrm{~N}$ $\mathrm{H}_{2} \mathrm{SO}_{4}$ stopped the reaction, and the absorbancy was read at $492 \mathrm{~nm}$ in a plate reader (Titertek Multiskan, Flow Laboratories, USA). Two positive and 10 negative control sera were included in each assay. Positive sera were obtained from patients who had IgM-RF by the latex agglutination test and IgE-RF by previous ELISA tests in the standardization of the assays. Negative sera were obtained from healthy children.

The results were expressed as ELISA index (EI) and calculated as follows: EI = absorbancy of serum samples / cut off, where cut off was determined as the mean absorbancy of the negative control serum plus 3 standard deviations. Samples presenting EI values $>1$ were considered positive.

\section{STATISTICS}

Statistical analysis consisted of determinations of geometric means with $95 \%$ confidence intervals (CI) for measurements of total serum IgE. Comparisons between the ages of children with JRA were performed using the Student $t$ test. This test was also used to compare the geometric means of total serum IgE. The positive and negative samples were listed in contingency tables and analyzed by the $\chi^{2}$ and Fisher exact tests ${ }^{24}$. Significance was accepted when $P<0.05$. Statistical calculations were performed using a standard Statistical Package Social Science (SPSS) program.

\section{RESULTS}

IgE-RF was detected in $15 / 91$ $(16.5 \%)$ patients with JRA and 4/45 $(8.9 \%)$ children from the control group $(P>0.05)$ (Fig. 1A). Disease onset was systemic in $7(18.4 \%)$, pauciarticular in $5(17.8 \%)$, and polyarticular in 3 (12\%) (Fig.1B).

An attempt was made to compare IgE-RF-positive and negative patients in the JRA groups. Comparisons of the most significant clinical features between the groups (with or without IgE$\mathrm{RF}$ ) are shown in table 2. There was no significant difference between the clinical and laboratory factors (disease activity, erythrocyte sedimentation rate, antinuclear antibody, or functional and radiological class III or IV) and the presence or not of the IgE-RF, except for the log of geometric mean of the total serum IgE, which was significantly higher $(P=0.03)$ in the group of patients with positive IgE-RF (Table 2).

The presence or absence of IgE-RF in sera from JRA patients and control children was analyzed in comparison to total serum IgE (Fig. 2). There was a significant difference $(P<0.05)$ in the geometric mean of total $\mathrm{IgE}$ between JRA patients with positive (1420 IU/ $\mathrm{mL}$ ) and negative (402 IU/mL) IgERF. In contrast, no statistically significant difference was found between positive $(157 \mathrm{IU} / \mathrm{mL})$ and negative $(117 \mathrm{IU} / \mathrm{mL}) \mathrm{IgE}-\mathrm{RF}$ in the control group $(P>0.05)$. In addition, the mean of total IgE values for JRA patients 

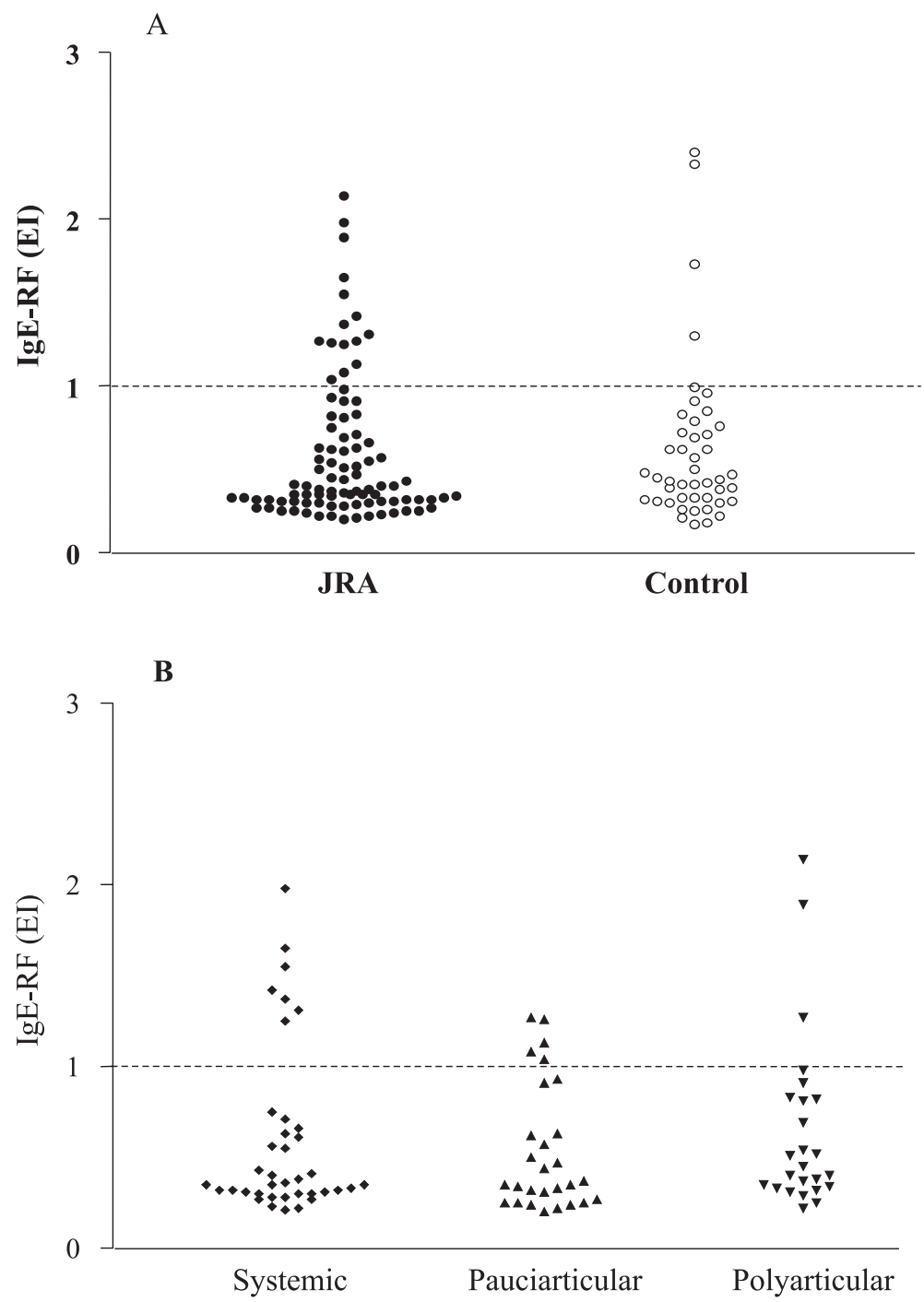

Figure 1 - Levels of IgE-RF expressed in ELISA Index (EI). (A) Patients with JRA ( $\mathrm{n}=91)$ and control children $(n=45)$. (B) JRA patients distributed according to the systemic $(n=38)$, pauciarticular $(n=28)$, and polyarticular $(n=25)$ disease onset. The dashed line represents the cut off of IgE-RF ELISA (EI $>1)$. with IgE-RF was higher than that obtained for IgE-RF-positive control children, although the difference was not statistically significant $(P=0.055)$.

The geometric mean of total serum IgE for all JRA patients (495 IU/mL) was significantly higher than for the control group (121 IU/mL), $P<0.0001$ (Fig 3).

\section{DISCUSSION}

The pathogenic role of the rheumatoid factor isotypes in JRA is not fully understood $^{14}$. The importance of the $\operatorname{IgM}$ isotype detected by agglutination methods is clear in terms of the classification and prognosis of this disease, because this isotype defines the seropositive polyarticular subtype, and it is related to progression to erosive disease $^{4}$. However, few studies are available on other RF isotypes in $\mathrm{JRA}^{14}$. Only 1 investigation assessing the presence of IgE-RF in children with JRA was found in the literature ${ }^{17}$. Eleven out of 26 children studied (42\%) presented weakly positive reactions (undiluted sera) for IgE-RF when tested by indirect immunofluorescence $^{17}$.

In our study, IgE-RF was detected by ELISA in $15(16.5 \%)$ of 91 children with JRA, and this detection was not

Table 2 - Laboratory and clinical features among 15 patients with positive FR-IgE with juvenile rheumatoid arthritis (JRA) and 76 patients with negative IgE-RF.

\begin{tabular}{llll}
\hline Laboratory and Clinical Features & $\begin{array}{c}\text { Positive IgE-RF } \\
\mathrm{n}(\%)\end{array}$ & $\begin{array}{c}\text { Negative IgE-RF } \\
\mathrm{n}(\%)\end{array}$ & $\begin{array}{c}P \\
\mathrm{X}^{2} \text { or Fisher }\end{array}$ \\
\hline Active disease & $8(53.3)$ & $42(55.3)$ & $\mathrm{NS}$ \\
Erythrocyte sedimentation rate $(>20 \mathrm{~mm} / \mathrm{h})$ & $7(46.7)$ & $47(61.8)$ & $\mathrm{NS}$ \\
Antinuclear antibody $(+)$ & $4(26.7)$ & $15(19.7)$ & $\mathrm{NS}$ \\
Rheumatoid factor (latex agglutination +$)$ & $2(13.3)$ & $3(3.9)$ & $\mathrm{NS}$ \\
Functional class (III/IV) & $2(13.3)$ & NS & $\mathrm{NS}$ \\
Radiological class (III/IV) & $7(46.7)$ & $42(55.3)$ & $P=0.03$ \\
Log (geometric mean) of the total serum IgE & $3.2 *$ & 2.2 & \\
\hline
\end{tabular}

NS = Not significant 


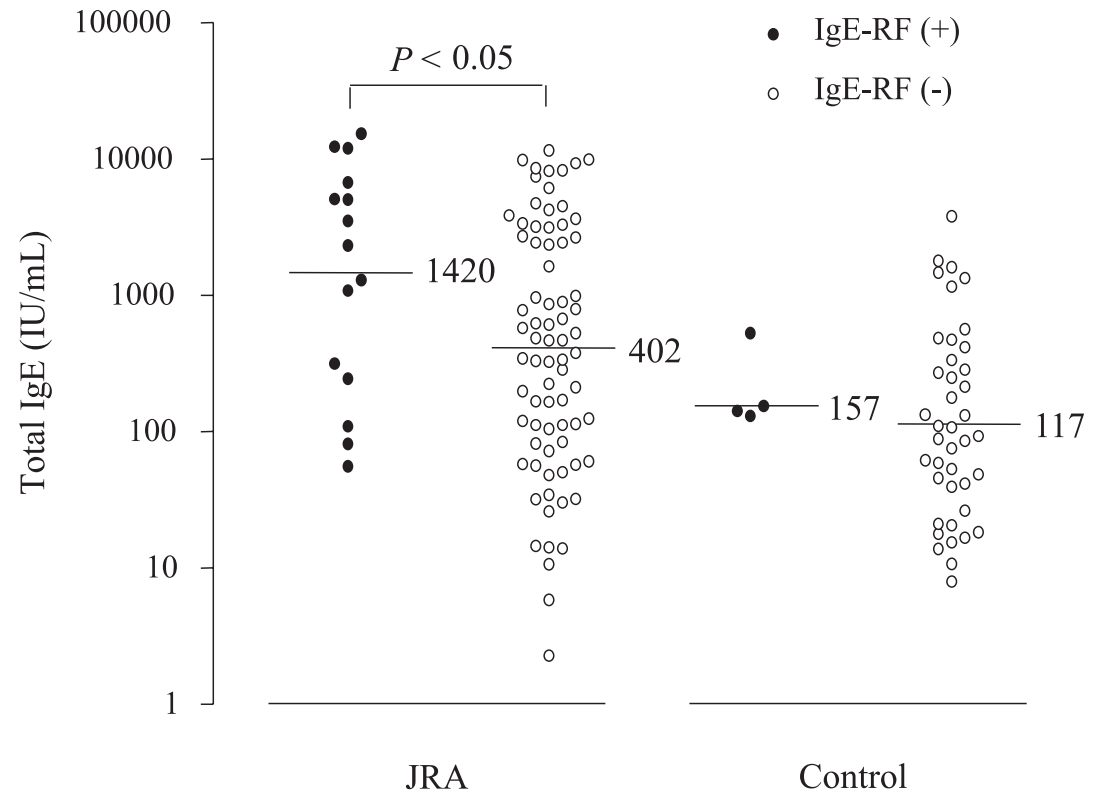

Figure 2 - Levels of total serum IgE in JRA patients with positive IgE-RF $(\mathrm{n}=15)$ and negative $\operatorname{IgE}-\mathrm{RF}(\mathrm{n}=76)$, and control children with positive $\operatorname{IgE}-\mathrm{RF}(\mathrm{n}=4)$ and negative $\operatorname{IgE}-\mathrm{RF}(\mathrm{n}=$ 41). The horizontal bars indicate the geometric means.

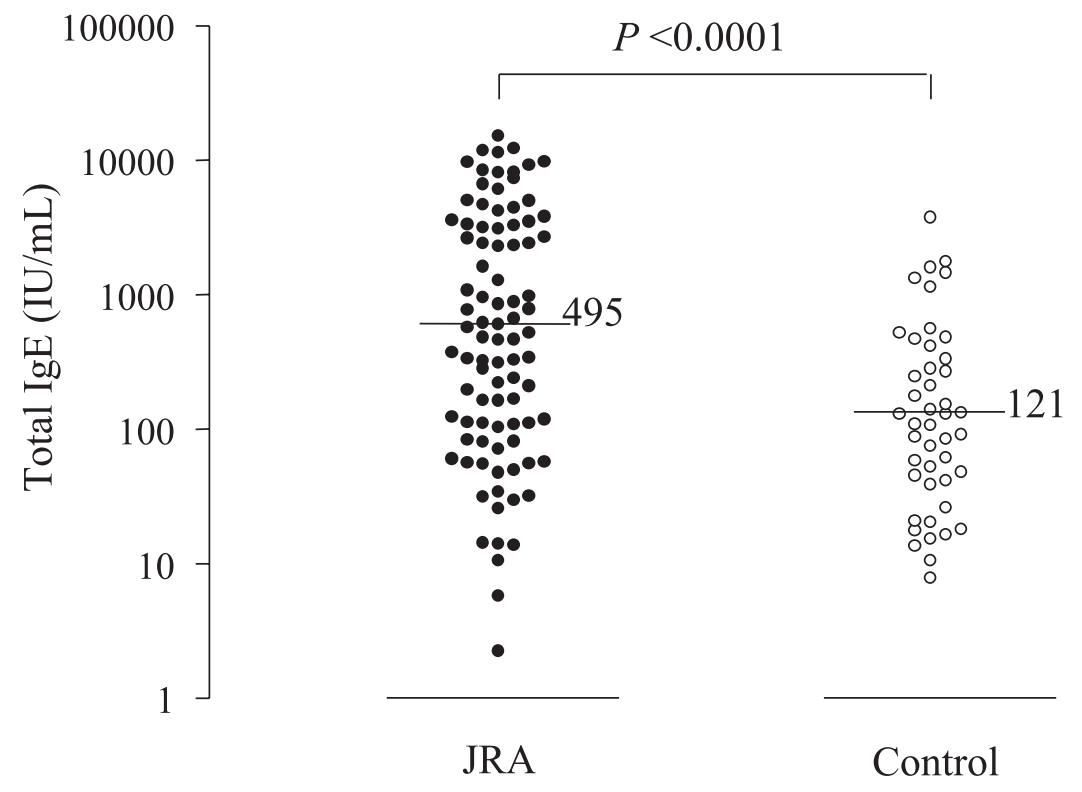

Figure 3 - Levels of total serum IgE expressed in IU/mL in the group of JRA patients $(n=91)$ and control children $(n=45)$. The horizontal bars indicate the geometric means.

related to the disease onset type. No correlation was observed between the presence of IgE-RF and any clinical or laboratory parameter. Previous studies have shown that low serum IgE-RF concentrations are detected in approxi- mately half the patients with rheumatoid arthritis, and high concentrations are detected in patients with vasculitis and other extra-articular manifestations and in patients with Felty's syndrome $\mathrm{e}^{15,16,25}$.
In our study, IgE-RF was detected in $4(8.9 \%)$ control children, and at high concentrations in some of them, indicating a low specificity of this antibody. The children in this group were considered healthy, with no clinical history suggestive of atopy. However, it should be emphasized that in the patients with JRA studied here, the presence of IgE-RF was correlated with higher serum IgE concentrations, whereas this was not observed in the IgE-RF positive control group. These data seem to indicate that the stimuli responsible for IgE-RF production is different in healthy individuals and in patients with JRA.

The identification of IgE-RF in a group of patients with JRA stimulates the discussion of the role of this autoantibody and consequently of the IgE-dependent mechanisms involved in the pathogenesis of this disease. The prevalence of atopic disease in children with JRA is unknown. It has been reported that the incidence of IgE-specific antibodies against pollen allergens in 40 children with JRA was similar to that expected for the normal population $^{26}$. Some studies have suggested that the prevalence of atopy among adults with rheumatoid arthritis is equal to or lower than that observed in the normal population, although high concentrations of total serum IgE have been detected in these patients ${ }^{14,26}$. Recently, Millauer in 1999, comparing patients with rheumatoid arthritis and patients with allergic diseases, observed that rheumatoid sera have high concentrations of total serum IgE and complexed anti-IgE, in addition to increased reactivity of specific IgE against only 1 allergen (Alternaria) and not against 9 other common allergens. Based on these findings, the authors concluded that the presence of large amounts of $\operatorname{IgE}$ probably does not result in an increased prevalence of allergic diseases in patients with rheumatoid arthritis, as previously mentioned ${ }^{14}$. On the other 
hand, the presence of anti-IgE antibodies seems to be paradoxical. According to these authors, it is possible that anti$\mathrm{IgE}$ antibodies may interfere with $\mathrm{IgE}$ binding, thus preventing the sensitization of basophils and mast cells ${ }^{34}$.

Some interesting studies have demonstrated the presence of activated mast cells in experimental rheumatoid lesions ${ }^{27}$ and in synovial fluid of pa- tients with rheumatoid arthritis and $\mathrm{JRA}^{28}$, the increased expression of the $\mathrm{CD} 23$ antigen in peripheral mononuclear cells of patients with rheumatoid $\operatorname{arthritis}^{29,30}$ and JRA ${ }^{31}$, and the reproduction of an experimental model of arthritis by the inoculation of monomeric or complexed $\operatorname{IgE} \mathrm{E}^{32,33}$. However, the value of these findings for the understanding of the physiopathological mechanisms involved in rheumatoid synovitis is uncertain.

In conclusion, IgE-RF can be detected in some patients with JRA with higher total serum IgE levels. We believe that the results reported here suggest an alteration of the humoral immune response in some children with JRA and stimulate future research lines aiming at the study of the IgE-dependent biological mechanisms involved in this disease.
FERREIRA RA e col. - Fator reumatóide-imunoglobulina E na artrite reumatóide juvenil. Rev. Hosp. Clín. Fac. Med. S. Paulo 57(5):209-216, 2002.

OBJETIVOS: Determinar os níveis séricos do fator reumatóide-imunoglobulina E na artrite reumatóide juvenil e correlacioná-los com parâmetros clínicos e laboratoriais.

MÉTODOS: Estudo multicêntrico prospectivo, realizado entre janeiro de 1993 a janeiro de 1999 com participação de três centros de reumatologia pediátrica. Estudaram-se 91 crianças com o diagnóstico de artrite reumatóide juvenil de acordo com os critérios do Colégio Americano de Reumatologia: $38(42 \%)$ com a forma de início sistêmica, $28(31 \%)$ pauciarticular e 25 (27\%) poliarticular. A idade variou de 2,1 a 22,6 anos (média de 10,5 $\pm 4,7$ anos) e 59 (65\%) crianças eram do sexo feminino. O grupo controle constituiuse de 45 crianças sadias. A detecção do fator reumatóide-imunoglobulina $\mathrm{E}$ foi realizada através de um ensaio imunoenzimático. Associações do fator reumatóide-imunoglobulina $\mathrm{E}$ com: fator reumatóide-imunoglobulina $\mathrm{M}$ (látex), imunoglobulina $\mathrm{E}$ sérica total, VHS, FAN, classe funcional e radiológica III ou IV foram analisadas.
RESULTADOS: Das 91 crianças com artrite reumatóide juvenil, quinze $(16,5 \%)$ apresentaram fator reumatóideimunoglobulina E positivo. Destas, $7(18,5 \%)$ na forma sistêmica, $5(18 \%)$ na pauciarticular e $3(12 \%)$ na poliarticular. Observou-se correlação estatisticamente significativa entre o fator reumatóide-imunoglobulina $\mathrm{E}$ e a média geométrica da imunoglobulina $\mathrm{E}$ sérica total no total dos pacientes com artrite reumatóide juvenil; não foi observada correlação estatística entre o fator reumatóide-imunoglobulina $\mathrm{E}$ e positividade para o Látex, VHS, FAN e classe funcional e radiológica 3 ou $4 \mathrm{em}$ nenhuma das formas de início da do- 
ença. Dos 45 controles, 4 (8,9\%) também apresentaram fator reumatóideimunoglobulina $\mathrm{E}$ positivo, mas não houve correlação com a imunoglobulina E sérica total.

CONCLUSÕES: O fator reumatóide-imunoglobulina $\mathrm{E}$ pode ser detec- tado em 16,5\% dos pacientes com artrite reumatóide juvenil, especialmente naqueles com níveis elevados de imunoglobulina E sérica total. $\mathrm{O}$ fator reumatóide-imunoglobulina $\mathrm{E}$ parece não se associar com atividade ou gra- vidade da artrite reumatóide juvenil.

DESCRITORES: Fator Reumatóide. Imunoglobulina E. Artrite Reumatóide Juvenil. Ensaio imunoenzimático.

\section{REFERENCES}

1. SUTTON B, CORPER A, BONAGURA V et al. - The structure and origin of rheumatoid factors. Immunol Today 2000; 21(4): 177-182.

2. TIGHE H \& CARSON D A - Rheumatoid factor. In: KELLEY W N, HARRIS Jr. E D, RUDDY $S$ et al. - Textbook of rheumatology. $5^{\text {th }}$ ed. Philadelphia, Saunders, 1997. p. 241249.

3. PETTY RE, CASSIDY JT \& SULLIVAN DB - Serologic studies in juvenile rheumatoid arthritis: a review. Arthritis Rheum 1977; 20 (suppl.): 260.

4. SCHALLER JG - Juvenile rheumatoid arthritis. Pediatr Rev 1997; 18 (10): 337-349.

5. EICHENFIELD AH, ATHREYA BH, DOUGHTY RA et al. - Utility of rheumatoid factor in the diagnosis of juvenile rheumatoid arthritis. Pediatrics 1986; 78 (3): 480 - 483.

6. CASSIDY JT \& PETTY RE - Juvenile rheumatoid arthritis. $3^{\text {th }}$ ed. Philadelphia, Saunder, 1995. p. 133-223.

7. ILOWITE NT, O'REILLY ME, HATAM L et al. - Expression of the rheumatoid factor cross-reactive idiotype in JRA: association with disease onset subtype, disease activity and disease severity. Scand J Rheumatol 1992; 21: 51-54.

8. ILOWITE NT, WEDGWOOD JF \& BONAGURA VR - Expression of the major rheumatoid factor cross-reactive idiotype in juvenile rheumatoid arthritis. Arthritis Rheum 1989; 32 (3): 265-270.

9. CASSIDY JT \& VALKENBURG H A - A five year prospective study of rheumatoid factor tests in juvenile rheumatoid arthritis. Arthritis Rheum 1967; 10: 83-90.
10.WALKER SM, SHAHAM B, McCURDY DK et al. - Prevalence and concentration of $\operatorname{IgM}$ rheumatoid factor in polyarticular onset disease as compared to systemic or pauciarticular onset disease in active juvenile rheumatoid arthritis as measured by ELISA. J Rheumatol 1990; 17 (7): 936-940.

11.JARVIS JN, POUSAK T \& KRENZ M - Detection of IgM rheumatoid factors by enzyme-linked immunosorbent assay in children with juvenile rheumatoid arthritis: correlation with articular disease and laboratory abnormalities. Pediatrics 1992; 90 (6): 945-949.

12.WALKER SM, McCURDY DK, SHAHAM B et al. - High prevalence of IgA rheumatoid factor in severe polyarticular-onset juvenile rheumatoid arthritis, but not in systemic-onset or pauciarticularonset disease. Arthritis Rheum 1990; 33 (2): 199-204.

13.VARBANOVA BB, BALEVA M, NIKOLOV K et al. - Prevalence of $-\operatorname{IgM},-\operatorname{IgA}$ and $-\operatorname{IgG}$ rheumatoid factors in seronegative polyarticular disease compared to pauciarticular disease in juvenile chronic arthritis as measured by ELISA. Adv Exp Med Biol 1999; 455: 61-68.

14.MILLAUER N, ZUERCHER AW, MIESCHER SM et al. - High $\operatorname{IgE}$ in rheumatoid arthritis (RA) patients is complexed with anti-IgE autoantibodies. Clin Exp Immunol 1999; 115 (1): 183-188.

15.MIZUSHIMA Y, SHOJI Y, HOSHI K et al. - Detection and clinical significance of IgE rheumatoid factor. J Rheumatol 1984; 11 (1): $22-26$.

16.BURASTERO SE, LO PINTO G, GOLETTI D et al. - Rheumatoid arthritis with monoclonal IgE rheumatoid factor. J Rheumatol, 1993; 20 (3): 489-494. 
17.PERMIN G \& EGESKJOLD EM - IgE anti-IgG antibodies in patients with juvenile and adult rheumatoid arthritis including Felty's syndrome. Allergy 1982; 37 (6): 421-427.

18.BREWER EJ, BASS J, BAUM J et al. - Current proposed revision of JRA criteria. Arthritis Rheum 1977; 20 (2) (supll.): 195199.

19.POLLART SM, CHAPMAN MD, FIOCCO GP et al. - Epidemiology of acute asthma: $\operatorname{IgE}$ antibodies to common inhalant allergens as a risk factor for emergency room visits. J Allergy Clin Immunol 1989; 83 (5): 875-882.

20.SILVA CHM - Contribuição para o estudo da imunoglobulina E (IgE) sérica total em crianças com artrite reumatóide juvenil. São Paulo, 1995. (Tese Doutorado em Pediatria - Faculdade de Medicina da Universidade de São Paulo).

21.STEINBROCKER O, TRAEGER CH \& BATTERMAN RE Therapeutic criteria in rheumatoid arthritis. JAMA 1949; 140: 659-662.

22.SILVA CHM - Fator reumatóide IgM detectado pelo teste de fixação do látex, reação de Waaler-Rose e ELISA em crianças com artrite reumatóide juvenil. São Paulo, 1990. (Dissertação Mestrado - Faculdade de Medicina, Universidade de São Paulo).

23.WILSON MB \& NAKANE PK - Antibody conjugated to horseradish peroxidase. In: KANPP K \& NOLUBAR GW (Eds.) - Immunofluorescence and related staining technique. Amsterdam, Elsevier Norths Holland Biomedical, 1978. p. 215224

24.TRIOLA MF - Introdução à estatística. 7. ed. Rio de Janeiro, LTC (Livro Técnico e Científico E.S.A.), 1999.

25.MERETEY K, FALUS A, BÖHM U et al. - IgE class immune complexes in Felty's syndrome: characterisation of antibody activities in isolated complexes. Ann Rheum Dis 1984; 43 : 246-250.

26.PESKETT SA, PLATTS-MILLS TAE, ANSELL BM et al. Incidence of atopy in rheumatic disease. J Rheumatol 1981; 8 (2): $321-324$.
27.CAULFIELD JP, HEIN A, HELFGOTT SM et al. - Intraarticular injection of arthritogenic factor causes mast cell degranulation, inflammation, fat necrosis, and synovial hyperplasia. Lab Invest 1988; 59 (1): 82-95.

28.GRUBER B, BALLAN D \& GOREVIC PD - IgE rheumatoid factors: quantification in synovial fluid and ability to induce synovial mast cell histamine release. Clin Exp Immunol 1988; 71 (2): 289-294.

29.CHOMARAT P, BRIOLAY J, BANCHEREAU J et al. - Increased production of soluble $\mathrm{CD} 23$ in rheumatoid arthritis, and its regulation by interleukin-4. Arthritis Rheum 1993; 36 (2): 234-242.

30.FERNÁNDEZ-GUTIÉRREZ B, HERNÁNDEZ-GARCÍA C, BAÑARES AA et al. - CD23 hyperexpression in rheumatoid arthritis: evidence for a B cell hyperresponsiveness to cognate and noncognate T-cell signals. Clin Immunol Immunopathol 1994; 72 (3): 321-327.

31.MASSA M, PIGNATTI P, OLIVERI $M$ et al. - Serum soluble CD23 levels and CD23 expression on peripheral blood mononuclear cells in juvenile chronic arthritis. Clin Exp Rheumatol 1998; 16 (5) : 611-616.

32.DE CLERCK LS, STRUYF NJ \& STEVENS, WJ - Activation of inflammatory cells by immune complexes containing $\operatorname{IgE}$ in serum and synovial fluid of patients with rheumatoid arthritis: a study using flow cytometric analysis. Ann Rheum Dis 1991; 50: $379-382$

33.DE CLERCK LS, STRUYF NJ, BRIDTS C $\mathrm{H}$ et al. - Experimental arthritis in rats induced by intra-articular injection of IgE aggregates: evidence of arthritogenic role of complexed IgE. Ann Rheum Dis 1992; 51: 210 - 213

34.GRUBER BL - Immunoglobulin E, mast cells, endogenous antigens, and arthritis. Rheum Dis Clin North Am, 1991; 17 (2): 333-342.

Received for publication on March 13, 2002. 